\title{
Remembering Dr. Sulayman Shehu Nyang (1944 - 2018)
}

Professor Jimmy Jones

Islamic Seminary of America

Before I entered Hampton Institute (now Hampton University) as a firstyear college student more than half a century ago, I had never met an African. Sadly, Africa for me was a monochromatic place shaped by Hollywood films where a White Tarzan reigned as "King of the Jungle." Although my Southern, racially segregated Roanoke (VA) public school education prepared me surprisingly well when it came to reading, writing, and arithmetic, it failed me and others miserably in terms of providing a panoramic view of world history and cultures. In my twelve years of social studies books, I do not recall there ever being a single lesson about an African or a Muslim of note.

All of this changed when I entered Hampton Institute as a new student in the fall of 1968. Suddenly I was thrust into a predominantly Black world that included Africans and Muslims who were not direct descendants of the forced African migration known as the Atlantic slave trade. During my first year I met and became close friends with Nelson Mkandawire of Malawi. What an eyeopening pan-African education that was, for I was not used to hearing about Africa's diversity and Black people being in charge of nations. The following year I met and became friends with Sulayman Shehu Nyang from The Gambia.

As a result of these close college friendships, my life and view of the world's history and cultures changed dramatically. Although I lost contact with Nelson after graduation, my relationship with Sulayman lasted for more than fifty years, right up until his death on November 12, 2018. For me, I remember my friend as an African, a bridge-builder, and a confidante.

As an African, Sulayman represented that powerfully positive essence of the human spirit that rightly emanates from the continent that scientists claim is the birthplace of humanity. Therefore, he was African in the sense that all human beings are African. Consequently, he felt at ease with people of varying cultural backgrounds. His engaging smile, incisive wit, and penetrating mind were always welcome in the many venues where he taught or collaborated. He was also "African" in the sense that, to the world, he represented sub-Saharan Africa's diverse peoples. Two good examples of his many writings on that region are his chapter on "Islam Revivalism in West Africa" in Religious Plurality in Africa: Essays in Honour of John S. Mbiti (2013; co-edited with Jacob K. Olupono) and 
his groundbreaking Islam, Christianity, and African Identity (1964), a classic text in the field.

As a bridge-builder, Sulayman spent his academic career as a public intellectual who always emphasized commonalities. This focus resulted in him being effortlessly "owned" by various groups in the Muslim American mosaic. Being an immigrant himself, organizations with large immigrant constituencies claimed him as their own without difficulty. As an African person of color, he easily moved within the African-American Muslim community. Given that these two groups represent the vast majority of Muslim Americans, it appeared to me that he was almost everywhere at once, from serving on the editorial board of the most prominent Muslim American publications to being a featured speaker, at one time or another, at every major gathering in the Muslim American community. In short, his connective, bridge-building impact was significant.

As a confidante, I could always depend on him to lend a sympathetic ear to whatever new community project I was contemplating or joining. Although our relationship was special because of its half century-plus longevity, I saw him patiently lend an attentive, sympathetic ear to the many people who often asked for advice at the end of one of his many lectures. Sulayman was always sympathetic, patient, helpful, and encouraging.

When my wife Chaplain Matiniah Yahya, Yale University, Muslim Omer Bajwa, and I were thinking about establishing the Islamic Seminary Foundation, one of the very first people I talked to was Sulayman Nyang. As usual, we had to chase each other a bit to get some face-to-face time together. Nevertheless, when we finally managed to meet, he was his usual enthusiastically supportive self while helping me consider this important venture's various facets. During our conversations, I even convinced him to allow me to nominate him as president of The Islamic Seminary of America - an effort that was, unfortunately, derailed by a series of health issues that ultimately led to his death.

In many ways this journal, our nine-year-old annual chaplain and imam conference at Yale, and the establishment of The Islamic Seminary of America in Dallas are a testament to the impact that one unapologetically African Muslim can have as a continuous bridge-builder and cheerleading confidante. May we continue his impactful legacy, and may Allah grant him paradise. 